\title{
Referendum as a Constitutional Right of Citizen Participation in Albania
}

\author{
Blendi Dibra, Adv. PhD Cand. \\ Master in Public Law \\ bdibra@gmail.com
}

Doi:10.5901/mjss.2015.v6n2s2p73

\section{Abstract}

\begin{abstract}
The referendum is one of the oldest forms of putting directly the democracy into use. The referendum represents a personal, direct statement of the citizens for any legal act or any "other matters of special importance", so that the state must take citizens' opinions before taking a decision. This notion implies the coexistence of sovereign representative bodies (assemblies) and direct popular intervention procedures. The idea of developing referendums in Albania for various issues, has become one of the main subjects of the political debates; especially when dealing with political disputes and the debate fails to find consensus. Although every political debate mentioning the idea of a referendum, once they have achieved the political consensus they let the will of the people in limbo. Unlike many other countries of the world, where the organization and development of referendums is common, leaving people the right to decide on certain issues, Albania after the dictatorship have been organised only three referendums. The referendum as a form of direct democracy is provided in the Constitution of the Republic of Albania in Articles 108/4, 150, 151, 152, 177/4, the Law No.7866, 10.06.2004 "On Referendums" and the Code election of the Republic of Albania in Articles 118-132. The paper analyses different forms of referendums as an important tool for the citizens' participations. A special attention is paid to the case in Albania. Below there is a brief analyse about the referendums in Albania by bringing the practice and facing it with albanian consitution provisions. Event though it is a common form of direct democracy in different countries, Albania has a poor experience which had faced several problems and arised different discussions through researchers of citizens participation right.
\end{abstract}

Keywords: citizens, referendum, constitution, government, decision-making

\section{Referendum}

The referendum is one of the oldest form of practicing directly the democracy. The referendum represents a personal, direct and secret statement of the citizens for any legal act or any "other matters of special importance" that the state must take citizens' opinions before taking a decision.

This notion implies the coexistence of sovereign governance and direct popular intervention procedures.

"Referendum" is the term given to a direct vote on a specific issue, in contrast with votes cast at elections, which are made in relation to parties or individual candidates and generally reflect voters' preferences over a range of different issues. Referendums may be held in relation to particular circumstances (e.g., to amend a country's constitution) or in relation to particular political issues (e.g., whether or not to join an international organisation) but are in general held in relation to issues of major political significance. The terms used to define referendums may differ in different countries; the following are the most common types of referendums held in countries across the world.

A referendum usually offers the electorate a choice of accepting or rejecting a proposal, but this is not necessarily the case. In Switzerland, for example, multiple choice referendums are common.

For easier study, referendums are usually classified using two criterias:

\section{According to the Type of the Act or Decision that is taken by the Referendum under this Criteria there is a Classification}

a- Constitutional Referendum means when the highest act of a state, in this case the Constitution, should be put to a referendum entering into force. In this case the referendum has constituent character or decision making character. Constitutive character means that Parliament should take the consent of the people before approving the constitution and as such, it is binding for the Parliament. Decision making charachter is expressed in those cases when the constitution is approved by parliament. Furthermore, asking the consent of the people in a referendum has such a binding character. 
b- Legislative Referendum is similar to that Constitutional except that in that case we are dealing with a particular law of a particular importance. In such cases parliament requires the consent of people through referendum. This referendum has a decision-making character or the referendum is organised before parliament approve it and in this case it has a constitutive character.

c- Political-statutory Referendum is seeking citizines ability not to deal with things that are not in a right manner and that have the will to decide on matters of political or statutory importance. This referendum is used when formed a new state, or when required the division from another state or when it comes to creation of a federation or confederation, in case of change of political regimes etc.

d- Local Referendum. in addition there is also a kind of referendum which compared to others is partial and is organised only in a few of territorial administrative units. This type of referendum is used in cases of local administrative matters such as in the case of investments in municipal infrastructure, investment in urbanism, etc.

\section{According to the Character or the Consequences of the Decision Making thorugh the Referendum, there are:}

a- Obligatory Referendumes. This type of referendum is used to decide about important issues, which are explicitely provided to be be decided through the referendum. This referendum has constitutive character and obliges state authorities to act on the basis of the results obtained in the referendum.

b- Facultative Referendum Compared with the Obligatory Referendumes, which is resoluted by law or any other action, the Facultative Referendum is not obligated for the state authorities. But this referendum is used in cases when the organ itself find it necessary such a thing. Even though it is not obligated, with its application it is converted as obligated for the state authorities and they need to follow it strictly. In contrast of obligatory referendum which is provided by law or by any other act, facultative referendum is not mandatory for state authorities to implement it, but used only when it is decided as necessary. Although not mandatory, on the occasion of his application the its results becomes obligatory to be applied from state authorities.

c- Consultative Referendum. The difference with the two other types of referendums is that this kind of referendum is not mandatory for state authorities and does not require them to apply. But it has more advisory character from which the state authorities may take appropriate decisions, based on the results of the referendum. So this kind advises, does not obligate.

\section{Arguments for and Against Referendums}

Supporters of the use of referendums argue that, in the context of increasing voter apathy and disenchantment with traditional forms of democracy, direct democracy can help to re-engage voters with politics and democracy. Another argument advanced in favour of referendums is that they can be used to resolve political problems, particularly for incumbent governments; where a governing party is divided over an issue, for example, holding a referendum can help reach a solution on the issue without splitting the party (one example of this is the 1975 UK referendum on whether the UK should remain in the EC, over which the ruling Labour government was deeply divided).

There are also a number of arguments made against the use of referendums. One is that it weakens representative government by undermining the role and importance of elected representatives. Another is that voters do not always have the capacity or information to make informed decisions about the issue at stake, and instead may make ill-informed decisions based on partial knowledge or on the basis or unrelated factors such as the economy or support for the government. This trend may be exacerbated in the case of referendums on complex issues such as constitutional change or international treaties, with which voters are likely to be unfamiliar.

Opponents of referendums also argue that, if the executive has the power to determine when referendums are held, they can be used as a political tool to suit the needs of the governing party rather than in the interests of democracy. They also claim that, since in many countries turnout at referendums is lower than at national elections, the argument that referendums increase the legitimacy of political decisions does not stand up. However, experts in Switzerland (where a number of direct democracy votes take place each year) believe that, although turnout at referendums is around $45 \%$, more than $45 \%$ of electors participate in direct democracy, since different voters participate in the different votes that interest them. 


\section{The Referendums in Albania}

The idea of developing referendums in Albania on various issues, has become the main subject of political debates, especially when dealing with political disputes and that the political debates fail to find consensus. Although every political debate mention the idea of a referendum, once its achieved the political consensus the will of the people is left in limbo.

Unlike many other countries of the world, where the organization and development of referendums is common, leaving people deciding by their own on certain issues, Albania after the dictatorship have only been organised three referendums.

The first one was hold in 1994 for the the purpose of approving the new Albanian Constitution. The second was on 29 June 1997. The referendum was organised together with the elections for the new parliament, where citizens voted if Albania should be a monarchy or a republic. A year later, in 1998, a popular referendum was organised to vote for the Constitution of the Republic of Albania.

The referendums focused on organising referendums about local issues and that should be noted that the initiative for organising it request only 10 percent of the signatures of the municipality's or commune's population. The organisation of the local referendum can be requested as well by a number of municipal or communal councils which represents not less than one third of the population of a region, about an local issue of local government issues at the regional level.

One of the most discussed in the field of law for local referendums in Albania remains the denial of the request to hold a referendum in Vlora which has been debated for years about building Petrol station named "La Petrolifiera" at the Adriatic coast at the city of Vlora. In this case by the the majority of the votes the Central Election Commission (CEC) has denied the request for a referendum.

From the point of view of the Albanian laws, it has an uncertainty about the competence of the CEC to decide about the object of the referendum, to review its content and relations it creates with the legal framework. In my opinion CEC has no such jurisdiction as neither the Constitution nor the Electoral Code, ninth section of which sets out the legal framework for referendums, by not mandating CEC to enter the judgment of the object and the content of referendums. ${ }^{1}$

The right to judge on the content of referendums the Albanian law recognizes only to two institutions:

1. The President of the Republic, who "decides whether or not" only for the referendums "on issues of a particular importance"2

2. The Constitutional Court which is the competent body to judge "about the constitutionality of the referendum and verifying its results" and that, in a determined order - for the "constitutional referendum" and "general referendum" 3 .

Regarding the constitutionality of the referendum, the Court must verify whether, in the case under consideration are present restrictions of the type envisaged by Article 151, paragraph 2 of the Constitution, which makes it necessary to interpret this provision.

Taking the example of the citizens' of Vlora demand for a referendum because of the "La Petrolifera" issue that questions naturally whether there is a legal right local community expressed through the referendum on such an issue that is related to the environment?

The virtue of the "On Environmental Protection" principle which termed "the awareness and public participation in environmental decision-making" as one of the "basic principles of environmental protection". This law stipulates that "local government represent the most important governmental structure for the management and protection of the environment under their jurisdiction". In the process of environmental impact assessment and strategic environmental assessment under the legal definition attended by all stakeholders, "it is especially the local government, public and environmental nongovernmental organizations" which has given the constitutional principle according to "local self-government units is exercised through their representative organs and local referendum" environmental law. It expressly recognizes the "public and non-profit organizations" right to request" general organization of referendums or partial environmental issues". Principles and norms of international law contained in the reports of the public to environmental issues, have become an integral part of the Albanian positive law, and, as such "guarantee public access to environmental information, to participation in the environmental decision making and access to justice in relation to environmental issues".

\footnotetext{
1 "CEC decides to accept or reject the request - sanctioned in Article 122, Paragraph 2 of the Electoral Code are based only on the regularity of the presented documentation"

2 article 129, point 3, Electoral Code

${ }^{3}$ article 129, point 2, Electoral Code
} 


\section{Referendum as an Expression of Sovereignty}

Article 177 and Article 150 of the Constitution regulate the various procedures and ensure fair referendum, from one side to the Parliament, as the representative of authority delegated by the people (Article 2.2 of the Constitution); and on the other hand, for the people, to whom belongs the sovereignty of the Republic of Albania (Article 2.1 of the Constitution).

The spirit of the Constitution and its specific provisions, so far, guaranteeing the right of the people (the sovereign) to repeal any law passed by Parliament, except those explicitly defined in Section 151.2 of the Constitution. These are the only laws in order to determine more precisely the correct and for which has not been granted to the people by the Constitution repealed by referendum. For any other law, including the revision of the Constitution, or other relevant laws, the people have the right to exercise its powers through a referendum abrogues. Actually, the article no. $117^{10}$ of the constitution fixes the procedures for "consitutional referendums". Their designation in this way has to do with the fact that this referendum is required for approval or the ratification of the consitutional changes. It is obvious that in this case we are dealing with the Consultativ Referendum, or in other words "citizens consultation". This kind of referendum cannot be initialised by the citizens (via 50.000 voters), but it is anticipated as a possible procedure for the adoption of consitutional amendments, the permission for thir use, or consultations with the citizens for the presentation of the special attention laws (this kind of referendum is stipulated on the articles 177.4, 177.5, 150.2 of the Constitution).

In all cases, Consultativ Referendum is developed before the legal norms (amendment, draft-law) have the legal permision for their use, and unless it is considered necessary by the proceeding body. Certainly that the Consultativ Referendum expresses in a straightforward way the will of the citizens, and that means that the mass has the power, but in this case, it is not straightforward. We need to distinguish the direct expression of the citizens' will from the direct action of the citizens. There is another case of the will expressed directly by the citiziens - general elections; and there is no practice of the sovereignty but a procedure for the pass of the right to practice it to the elected representatives.

Direct practice of the sovereignty is when the citiziens, in accordance to the specific procedures, without being conditioned from the will of any other organ, initiates and concludes a legal process expressing directly its will, which creates legal consequences.

This case is anticipated only in the article no. 150.1 of the Albanian Republic Constitution. Unless it is intialised a general referendum fot the repeal of a laq, after the completion of the formal and procedurial papers, that no "authority body" has the possibility to "prevent" its development. This is the direct practice of the sovereignty, as it is mentioned in the article no. 2.1 of the Constitution.

It is needed the clear differentiation between a amendment (review) process practiced by citizens power and an abrogation process (repeal, derogation) exercised by another branch (in this case refer to formally sovereign supreme power). According to the Constitution of the Republic of Albania, in any case that will undertake a process to amend the Constitution, therefore, a positive legislative process, clearly must follow procedures laid down in Article 177.

General abrogative referendum has nothing to do with the process of amendment. Through abrogative referendum provision may only remain without power, turning the legal rate in the previous situation (when we repeal of an amendment), or leaving the legal relationship. In the second case, a positive process begins immediately legislative body to extract new legal rate according to procedures. More clearly, in the second case, the referendum repealed a constitutional provision, the Assembly begins proceedings under Article 177 for the adoption of new legal norm regulating the corresponding relationship.

Article 177 of the Constitution establishes a procedure that follows the Albanian Parliament to amend the constitution, while section 150.1 defines a general security, in fact the only control of people (the) on whose authority has passed the right to exercise sovereignty (Assembly). In any case, the practice of sovereignty by selected representatives is checked and after being elected the representatives of sovereignty practiced primarily through the issuance and enforcement of laws, the right to abolish laws is the only means of control, (but highly effective) against elected representatives. The only laws, which people have removed the right to control themselves, are those mentioned in Article 151.2 of the Constitution." Issues related to the territorial integrity of the Republic of Albania, the restriction of freedoms and human rights, the budget, taxes and financial obligations of the state, and the lifting of state of emergency, declaration of war and peace and the amnesty cannot be submitted to a referendum". This is the position of the sovereign who adopted the Constitution and only for those laws he has given the right to himself.

This has to do with the special nature of these laws that makes it impossible to be submitted to an objective popular judgment. There is not even the Constitution of the Republic, as the highest law of the Republic, or amended laws.

Constitutional amendments, to change one or several provisions of the Constitution, as the form, the content, are in themselves elements of a law, therefore, under Article 150 of the Constitution the people through 50,000 voters have 
the right to request repeal of this law, without prejudging the outcome of the referendum . In the end, put the people themselves, as if the amendments will not be canceled, meaning that it is the right one is adopted. Albanian legislation has oriented referendums' options, while the institution of the referendums determining (ratification, suspension or rescinding) is specifically prescribed by law: constitutional referendum, for the total and for a referendum on an issue of particular importance.

While consultative referendums regarding Albanian jurisprudence through decisions of the Supreme Court, despite more than modest experience of the practice of referendums, has been identified as an essential feature of a consultative referendum, the fact that he and his score directly produces no obligation to relevant to intervene in the content of the normative act on a specific issue, to suspend or abolish it.

The decision as voters as well as the Assembly to pass a referendum will be reviewed by the Constitutional Court. This control is very important because the phrase "issues of particular importance" are reviewed by the Constitutional Court because it is a very general term that can be abused. The Constitutional Court considers that the review of the constitutionality of the requirement for a referendum, calls for clarification of the general conditions associated with the institution of the referendum in general and the abolishment in particular, in view of Article 151 of the Constitution .

In a general perspective, the position of the constitutional referendum as a tool, is linked to the notion of sovereignty ${ }^{4}$, which is exercised by representatives chosen by him ${ }^{5}$, In this regard, the fundamental importance takes the issue of determining the conditions and cases in which people can practice sovereignty firsthand. According to the doctrine, the principle of the practice of sovereignty by people, implies a democratic concept according to the criteria of a representative democracy that contains elements enabling the direct practices of constitutional democracy. This means that people with the right to practice the legislative function, normally not for themselves directly but through their elected representatives.

The Assembly may decide an international agreement to be ratified by the referendum. The idea was that if such an agreement does not unanimity within a political force that has the power, it calls people to solve its dilemma. Furthermore, the Constitution recognizes the local referendums, or in other words referendums that are held by local governments. In this case the referendum is held at the time as one or several territorial administrative unit .

Voters do not have the right of initiative to amend the Constitution. In this sense, the initiative to challenge the law on the Electoral Code is an inefficient operation. Such an initiative belongs to the Assembly. Assembly has no draft constitutional obligation to lead to a vote by referendum. $3 / 5$ of the members of Parliament are enough to make such changes. It belongs to the political realities of the moment and the desire to know the opinion of the sovereign (the people) to decide whether an amendment will be voted by the referendum.

\section{References}

Kuvendi i Shqipërisë."Kodi Zgjedhor i Republikës së Shqipërisë“ Ligji Nr 10 019, datë 29.12.2008 (ndryshuar me ligjin nr.74/2012) Kuvendi i Shqipërisë."Për Referendumet" Ligji Nr 7866, datë 06.10.1994.

Kuvendi i Shqipërisë."Për Ratifikimin e Konventes se Aarhusit për të drejtën e publikut për të pasur informacion, për të marrë pjesë në vendimmarrje dhe për t'iu drejtuar gjykatës për çështjet e mjedisit"' Ligji Nr 8672, datë 26.10.2000.

Kushtetuta e Republikës së Shqipërisë, me interpretime të Gjykatës Kushtetuese, mbledhur dhe përgatitur nga Ardita Alsula, 2008 Tiranë: Alb Juris

Meidani, Rexhep. 2009. "Mbi Qeverisjen", Tiranë: Shtëpia botuese "DUDAJ"

Popper, Karl. 2009. "Për filozofinë dhe shkencën", Tiranë: Shtëpia botuese "Fan Noli

Sokoli, Lekë. 2008. "Refleksione Sociologjike", Tiranë: Dita 2000

Sokoli, Lekë. 2009. "Metodat e kërkimit në shkencat sociale", Tiranë: Instituti i Sociologjisë

${ }^{4}$ Article $2 / 1$ of the Constitution
${ }^{5}$ Section 2.2 
